\title{
Determination of Yield and Plant Characteristics of Some Silage Corn Varieties
}

\author{
Bilal KESKINN ${ }^{1}$, Süleyman TEMEL ${ }^{1}$, Barış EREN ${ }^{1}$
}

\begin{abstract}
The study was conducted to determine yield and some plant characteristics in some silage corn varieties grown as the main product in Igdir province ecological conditions. The study was established to randomized complete block design pattern with three replications in irrigating conditions. In this research, plant height $(\mathrm{cm})$, forage yield $\left(\mathrm{t} \mathrm{ha}^{-1}\right)$, fodder ratio (\%), dry matter yield $\left(\mathrm{t} \mathrm{ha}{ }^{-1)}\right.$, leaf ratio (\%), stem ratio (\%), cob ratio (\%), the number of leaf (number/ plant), plant weight (g) were determined in 10 silage corn varieties. According to results; plant height between $204.2 \mathrm{~cm}$ (OSSK-602) and $313.9 \mathrm{~cm}$ (OSSK-644), forage yield $60.5 \mathrm{tha}^{-1}$ (OSSK-602) and $110.5 \mathrm{t} \mathrm{ha}^{-1}$ (TK-6063), hay ratio 30.3\% (OSSK-644) and 38.6\% (TK-6063), hay yield $20.3 \mathrm{t} \mathrm{ha}^{-1}$ (OSSK-602) and $41.5 \mathrm{t} \mathrm{ha}^{-1}$ (TK-6063), ), leaf ratio $14.3 \%$ (OSSK- 596) and 18.3\% (RX-9292), stem ratio $42.3 \%$ (Hido) and $51.0 \%$ (OSSK-644), cob ratio 36.0\% (OSSK-644) and 45.6\% (OSSK-602), the number of leaf 11.0 (OSSK-602) and 13.3 $\mathrm{g}$ (TC-6063) plant weight $635.9 \mathrm{~g}$ (OSSK-602) and $1160.6 \mathrm{~g}$ (TK-6063) was found. As a result, TK-6063, Hido and Shemall varieties has been found suitable for region ecology, respectively.
\end{abstract}

Keywords: Plant characteristics, silage corn varieties, yield

\section{Bazı Silajlık Mısır Çeşitlerinin Verim ve Bitkisel Özelliklerinin Belirlenmesi}

ÖZET: Bu çalışma Iğdır ekolojik şartlarında ana ürün olarak yetiştirilen bazı silajlık mısır çeşitlerinin verim ve bazı bitkisel özelliklerini belirlemek amacıyla yürütülmüştür. Araştırma, sulu koşullarda 3 tekerrürlü olarak şansa bağlı tam bloklar deneme desenine göre kurulmuştur. Araştırmada, 10 silajlık mısır çeşidinin bitki boyu, yeşil ot verimi, kuru ot oranı, kuru ot verimi, yaprak oranı, sap oranı koçan oranı, yaprak sayısı ve bitki ağıllığı belirlenmiştir. Araştırma sonuçlarına göre, bitki boyu $204.2 \mathrm{~cm}$ (OSSK-602) ve $313.9 \mathrm{~cm}$ (OSSK-644), yaş ot verimi $60.5 \mathrm{t} \mathrm{ha}^{-1}$ (OSSK-602) ve $110.5 \mathrm{t} \mathrm{ha}^{-1}$ (TK-6063), kuru ot oran1 \%30.3 (OSSK-644) ve \%38.6 (TK-6063), kuru ot verimi $20.3 \mathrm{t} \mathrm{ha}^{-1}$ (OSSK-602) ve $41.5 \mathrm{t} \mathrm{ha}^{-1}$ (TK-6063), ), yaprak oran1 \%14.3 (OSSK- 596) ve \%18.3 (RX-9292), sap oranı \%42.3 (Hido) ve \%51.0 (OSSK-644), koçan oran1 \%36 (OSSK-644) ve \%45.6 (OSSK-602), bitkide yaprak sayıs1 11.0 (OSSK-602) ve 13.3 (TC-6063) bitki ağırlı̆̆ $635.9 \mathrm{~g}$ (OSSK-602) and $1160.6 \mathrm{~g}$ (TK6063) arasında bulunmuştur. Sonuç olarak, bölge şartlarında en uygun mısır çeşitlerinin TK-6063, Hido ve Shemall olduğu bulunmuştur.

Anahtar kelimeler: Bitkisel özellikler, silajlk mısır çeşitleri, verim

Iğdır Üniversitesi, Ziraat Fakültesi, Tarla Bitkileri, Iğdır, Türkiye

Sorumlu yazar/Corresponding Author: Bilal KESKIN, bilalkeskin66@yahoo.com 


\section{INTRODUCTION}

In recent years, production of silage fodder crops was increased because of that increase of quantities in forage production is inadequate and especially insufficient nutrition of the animals in winter season depend on increasing number of animals in Turkey. In this sense, maize (Zea mays L.) a forage crop that providing food requirement of animals and using as silage in the our country and the world (Basbag et al., 1997). Maize has been accepted, especially in the last half century, as a plant that increasing production Worldwide regarding silage fodder production due to high nutrition value and deliciousness characteristic. Furthermore, the high forage yield per unit area and suitable for silage without the additive are among most important features of maize. The importance that given production of maize is increasing in terms of meeting feed deficit which is need of animals due to these features (Saglamtimur et al., 1998). There are a variety of plants used in the production of silage in our country. It appears that production of corn and sorghum among these plants are highest (Saglamtimur et al., 1998). The high forage yield is important in production of silage corn. Besides, the high forage yield depends on a long vegetation period. Because of the increase in the vegetation period the plant has provided high yield increases (Temel and Tan, 2002). The duration of the vegetation that is effect development of cob in silage corn production is significantly important (Ayaz et al, 2013). When need of rough age is not inadequate production, there are negative effects regarding livestock and animal products. Silage corn varieties should be utilized as animal feed in order to meet the needs of roughage in Igdir province has a convenient location, especially for agriculture. In this regard, silage corn production that will carry out in wet conditions in Igdir province is likely to have important effects on the silage production capacity of this region. In this study, we aimed that identification of suitable and highyielding hybrid varieties for silage corn production in the Igdir Plain which has appropriate vegetation period.

\section{MATERIALS AND METHOD}

This research was carried out in irrigated trial areas of the Agricultural Research and Application Center of the Igdir University in 2015. In this study, ten corn varieties (72 MAY 80, OSSK-644, TK-6063, OSSK-596, TK-6060, HIDO, RX- 9292, 71 MAY 69, SHEMALL, OSSK-602) were used. Climate values realized in 2015 of Igdir Province are given in Table 1.

Table 1. Average Climate Properties Values of Igdir Province in 2015

\begin{tabular}{lcccccccc}
\hline & March & April & May & June & July & August & September & Sum/Av \\
\hline Average Temperature $\left({ }^{\circ} \mathrm{C}\right)$ & 11.0 & 16.4 & 21.3 & 28.5 & 31.8 & 30.2 & 27.2 & 23.7 \\
Monthly Total Precipitation (mm) & 52.0 & 44.1 & 41.5 & 27.8 & 0.3 & 14.3 & 1.4 & 181.4 \\
Monthly Avg. Relative Humidity (\%) & 50.8 & 47.7 & 52.9 & 40.0 & 33.6 & 40.7 & 42.4 & 44.0 \\
\hline
\end{tabular}

Soils of the trial area have such as characteristics clay-loamy texture, severe alkaline $(\mathrm{pH}$ : 8.6, lightly salted (EC $1.37 \mathrm{dS} / \mathrm{m}$ ), low organic matter content, $(1.20 \%)$ and rich lime content (CaCO3: 22.27\%). Moreover, suitable phosphorus and potassium contents in the soil was determined as $51.7 \mathrm{ppm}$ and $852.4 \mathrm{ppm}$, respectively (Erdogan, 2013). Studies were designed as three replications according to randomized block pattern. Planting process has been made in a manner that row spacing, row top, parcel length and parcel width will be respectively $70 \mathrm{~cm}, 15 \mathrm{~cm}, 5 \mathrm{~m}$ and 3.5 $\mathrm{m}$ using the marker on 4.4.2015 date. Each plot area was $17.5 \mathrm{~m}^{2}$. In this research, total $160 \mathrm{~kg} \mathrm{ha}^{-1}$ nitrogen (Keskin et al., 2005), $80 \mathrm{~kg} \mathrm{ha}^{-1}$ phosphorus (Çelebi et al., 2010) fertilization to maize plants was carried out. Half of nitrogen fertilizer was give during planting, but the other half is provided after plants were $50 \mathrm{~cm}$ long. Cultural practices such as weed control and tractors 
anchors which are necessary from sowing to harvest process have been made. At the same time, the watering process was regularly made until the harvest by opening furrow after plants are 15-20 cm long. Harvest process was made on 07.09.2015 date. And then, yield and plant characteristics were determined by measuring over 30 corn plants randomly selected in each plot. Two plants taken from each plot were slightly faded in shade environment and then dried in a drying cabinet at $70^{\circ} \mathrm{C}$ for 24 hours to determine the fodder ratio of the plants. Fodder yield was obtained by multiplication forage yield and fodder ratio. Data obtained from the results of research that we were carry out in Igdir conditions were subjected to a variance analysis with SPSS packet program and Duncan's multiple comparison test was used for demonstrate differences between each other of varieties (SPSS, 1991).

\section{RESULTS AND DISCUSSION}

\section{Plant height (cm)}

Plant height of maize varieties used in the study is range from 204.2 to $313.9 \mathrm{~cm}$. In this study, the highest plant height and the lowest height is belong to OSSK644 and OSSK 602 varieties. However, the highest plant height was $242.6 \mathrm{~cm}$, and the lowest height was 143.7 $\mathrm{cm}$ according to result of study carried out in conditions of Van province by Akdeniz et al., (2004). The average plant height in maize has been reported to range from 1.5 to $3 \mathrm{~m}$ (Kun, 1997). The effect of genetic structure is an important factor affected plant height (Hallauer and Miranda, 1987). When studies related to plant height in maize plant considering, we can say that varieties used in the experiment is not low plant height and height of these varieties sorting close to other studies. It supposes that these differences in results are result from regional climate and soil characteristics. Because the hereditary properties of quantitative characters are very low and are significantly affected by environmental conditions.

\section{Forage yield (t ha'), fodder ratio (\%), fodder yield $\left(\mathrm{t} \mathrm{ha}^{-1}\right)$}

Forage yield is an important factor affecting silage yield (Ayaz et al., 2013). Forage yield in corn varieties used in the study were show statistically significant differences and yields ranged from 60.5-110.5 $\mathrm{t} \mathrm{ha}^{-1}$.
While the highest value of forage yield was TK6063, the lowest yield value was obtained from OSSK 602 variety. Iptas et al., (2004) have obtained values between 87.9 and $67.2 \mathrm{t} \mathrm{ha}^{-1}$ in forage yield as result of studies carried out in Tokat- Kozova conditions. Akdeniz et al., (2004) showed that the highest value in forage yield was $78.4 \mathrm{tha}^{-1}$, and the lowest values were $27.2 \mathrm{tha}^{-1}$ in their study.

Fodder yields in varieties are ranged from 14.6 to $7.4 \mathrm{tha}^{-1}$ (Akdeniz et al., 2004). Fodder ratio of 10 corn varieties used in the study ranged from 30.3 to $38.6 \%$. While the highest value of fodder ratio was TK 6063, the lowest fodder ratio was obtained from OSSK 644 variety. While the highest value of fodder yield among corn varieties used in this study was $41.5 \mathrm{t} \mathrm{ha}^{-1}$ (TK $6063)$, the lowest fodder yield value was $20.3 \mathrm{t} \mathrm{ha}^{-1}$ (OSSK 602). Iptas et al., (2002) have obtained that the highest value was $23.6 \mathrm{t} \mathrm{ha}^{-1}$ and the lowest value was $18.5 \mathrm{t} \mathrm{ha}^{-1}$ in fodder yield as result of studies carried out in Tokat- Kozova conditions.

Akdeniz et al., (2004) obtained values between $14.6 \mathrm{t} \mathrm{ha}^{-1}$ and $7.4 \mathrm{t} \mathrm{ha}^{-1}$ in fodder yield in the study carried out in Van conditions.

In result of our study carried out Igdir province conditions, we found that forage and fodder yields obtained from maize varieties was to be higher than the findings of other researchers. It is assume that these differences will be result from different varieties used in study and environmental conditions.

\section{Leaf ratio, stem ratio, cob ratio (\%)}

While leaf ratio between corn varieties used in the research that we conduct in Igdir conditions is insignificant, stem and cob ratio was significant. The stem and cob ratio of varieties are range from between 42.3-51.0\%, and 36.0-45.6 respectively.

While OSSK 644 variety has higher stem ratio, Hido variety has lowest stem ratio. The highest value and the lowest value in terms of cob ratio among corn varieties was belong to OSSK 602 and OSSK 644 varieties.

Akdeniz et al., (2004) obtained values of cob ratio with $38.2-49.0 \%$, and stem ratio with $28.1-43.6 \%$ in study carried out in Van conditions. 


\section{Leaf number (Units)}

Multiple comparison results belong to leaf number in maize varieties are given in Table 3. Values of between 11.0 and 13.3 in the number of leaves of the corn variety used in this study was obtained. According to our results, while TK 6063 variety has highest leaf number (13.3), OSSK 602 variety has lowest leaf number (11.0). Gunes and Acar (2006) was found that highest and lowest value in leaf number among maize varieties grown as the second production in a study carried out in Karaman is 15.8 and 13.8 pieces/plant, respectively.

Table 2: Plant height, forage yield, fodder ratio and fodder yield of maize varieties

\begin{tabular}{|c|c|c|c|c|}
\hline Varieties & $\begin{array}{c}\text { Plant height } \\
(\mathrm{cm})\end{array}$ & $\begin{array}{c}\text { Forage yield } \\
\mathbf{t ~ h a}^{-1}\end{array}$ & $\begin{array}{c}\text { Fodder ratio } \\
(\%)\end{array}$ & $\begin{array}{c}\text { Fodder } \\
\text { yield }\left(\mathrm{t} \mathrm{ha} \mathbf{h}^{-1}\right)\end{array}$ \\
\hline 72 MAY 80 & $250.3 \mathrm{bc}$ & $83.7 \mathrm{bcd}$ & $33.3 \mathrm{bcd}$ & $27.4 \mathrm{bc}$ \\
\hline OSSK 644 & $313.9 \mathrm{a}$ & $88.1 \mathrm{abc}$ & $30.3 \mathrm{~d}$ & $26.6 \mathrm{bc}$ \\
\hline TK 6063 & $242.5 \mathrm{bcd}$ & $110.5 \mathrm{a}$ & $38.6 \mathrm{a}$ & $42.6 \mathrm{a}$ \\
\hline OSSK 596 & $278.0 \mathrm{ab}$ & $95.0 \mathrm{abc}$ & $34.6 \mathrm{bcd}$ & $32.7 \mathrm{ab}$ \\
\hline TK 6060 & $242.1 \mathrm{bcd}$ & $96.7 \mathrm{abc}$ & $34.0 \mathrm{bcd}$ & $32.8 \mathrm{ab}$ \\
\hline HİDO & $242.8 \mathrm{bcd}$ & $109.4 \mathrm{a}$ & $35.0 \mathrm{bc}$ & $38.2 \mathrm{ab}$ \\
\hline RX 9292 & $237.1 \mathrm{bcd}$ & $87.7 \mathrm{abc}$ & $36.3 \mathrm{ab}$ & $31.8 \mathrm{abc}$ \\
\hline 71 MAY 69 & $230.4 \mathrm{~cd}$ & $82.2 \mathrm{~cd}$ & $36.6 \mathrm{ab}$ & $30.6 \mathrm{abc}$ \\
\hline SHEMALL & $260.8 \mathrm{bc}$ & $107.9 \mathrm{ab}$ & $33.6 \mathrm{bcd}$ & $36.5 \mathrm{ab}$ \\
\hline OSSK 602 & $204.2 \mathrm{~d}$ & $60.5 \mathrm{~d}$ & $33.6 \mathrm{bcd}$ & $20.3 \mathrm{c}$ \\
\hline Average & 250.2 & 91.7 & 34.6 & 31.9 \\
\hline
\end{tabular}

* There were not significant differences in $\mathrm{P}<0.05$ level among averages shown with same letter.

Table 3: Leaf ratio, stem ratio, cob ratio, leaf number and plant weight of maizevarieties

\begin{tabular}{|l|c|c|c|c|c|}
\hline Varieties & $\begin{array}{c}\text { Leaf ratio } \\
\mathbf{( \% )}\end{array}$ & $\begin{array}{c}\text { Stem ratio } \\
\mathbf{( \% )}\end{array}$ & $\begin{array}{c}\text { Cob ratio } \\
\mathbf{( \% )}\end{array}$ & $\begin{array}{c}\text { Leaf number } \\
\text { (Units) }\end{array}$ & $\begin{array}{c}\text { Plant weight } \\
\text { (g) }\end{array}$ \\
\hline 72 MAY 80 & 16.0 & $47.4 \mathrm{ab}$ & $39.3 \mathrm{~cd}$ & $13.2 \mathrm{a}$ & $879.0 \mathrm{bcd}$ \\
\hline OSSK 644 & 15.3 & $51.0 \mathrm{a}$ & $36.0 \mathrm{~d}$ & $13.0 \mathrm{a}$ & $925.2 \mathrm{abc}$ \\
\hline TK 6063 & 16.3 & $47.0 \mathrm{abc}$ & $39.6 \mathrm{~cd}$ & $13.3 \mathrm{a}$ & $1160.6 \mathrm{a}$ \\
\hline OSSK 596 & 14.3 & $48.3 \mathrm{ab}$ & $39.0 \mathrm{~cd}$ & $12.6 \mathrm{ab}$ & $997.8 \mathrm{abc}$ \\
\hline TK 6060 & 14.6 & $43.0 \mathrm{~d}$ & $44.6 \mathrm{ab}$ & $12.3 \mathrm{ab}$ & $1016.3 \mathrm{abc}$ \\
\hline HIDO & 18.0 & $42.3 \mathrm{~d}$ & $44.6 \mathrm{ab}$ & $13.0 \mathrm{a}$ & $1149.6 \mathrm{a}$ \\
\hline RX 9292 & 18.3 & $48.6 \mathrm{ab}$ & $38.3 \mathrm{~cd}$ & $13.0 \mathrm{a}$ & $921.6 \mathrm{abc}$ \\
\hline 71 MAY 69 & 18.0 & $47.0 \mathrm{abc}$ & $40.3 \mathrm{bcd}$ & $12.6 \mathrm{ab}$ & $863.8 \mathrm{~cd}$ \\
\hline SHEMALL & 16.0 & $44.6 \mathrm{bcd}$ & $43.0 \mathrm{abc}$ & $12.3 \mathrm{ab}$ & $1133.2 \mathrm{ab}$ \\
\hline OSSK 602 & 17.6 & $43.3 \mathrm{~cd}$ & $45.6 \mathrm{a}$ & $11.0 \mathrm{~b}$ & $635.9 \mathrm{~d}$ \\
\hline Average & 16.44 & 46.25 & 41.03 & 12.63 & 968.3 \\
\hline
\end{tabular}

* There were not significant differences in $\mathrm{P}<0.05$ level among averages shown with same letter. 


\section{Plant weight (g)}

Plant weights obtained in this study were significant among maize varieties. Multiple comparison results belong to plant weight in maize varieties are given in Table 3. The highest plant and the lowest plant weight in the study was measured as $1160.6 \mathrm{~g}$ and $635.9 \mathrm{~g}$. Gunes and Acar (2006) was determined that highest and lowest value in plant weight among maize varieties grown as the second production in a study carried out in Karaman is $1198.0 \mathrm{~g}$ and $913.6 \mathrm{~g}$, respectively.

\section{REFERENCES}

Akdeniz, H, Yılmaz İ, Andıç N, Zorer Ş, 2004. A Study on Yield and Forage values of Some Corn Cultivars. Yuzuncu Yil University Journal of Agricultural Sciences (YYU J Agr Sci.), 14 (1):47-51

Ayaz M, Özpınar H, Yaman S, Acar A, Aksu Y, Yavrutürk Y, Niksarlı İnal F, Aksu S, Aygün Y, 2013. Analysing Yield and Quality Characteristics of Silage Maize Cultivars which are Used Commonly or Could be Used for Second Crop. Harran Journal of Agricultural and Food Science, 17(3):1-11.

Başbağ M, Demirel R, Gül İ, Saruhan V, 1997. Opportunities to Grow Corn and Sorghum as a Material for Silage in The Region of South-Eastern Anatolia Project. The Republic Of Turkey the First Silage Congress. Hasad Publishing. 251-255. Istanbul.

Çelebi R, Çelen E, Çelebi Ş.Z, Şahar A.K, 2010. Effects of Different Nitrogen and Phosphorus Doses on The Silage Yield and Feed Value of Corn (Zea mays L.). Selçuk Agricultural and Food Science Journal, 24(4):16-24

Erdogan H, E, 2013. Soil Definition Guide., ISBN: 978-605-467220-2.

Güneş A, Acar R, 2006. The Determination of Growing Possibilities of Hybrid mazie Cultivars as Second crop Under Karaman Ecological Conditions. Selçuk Agricultural and Food Science Journa,1 20(39): 84-92.

\section{CONCLUSION}

The most important feature wanted silage corn production is high forage yield.

According to data obtained from the study we conducted, the most suitable varieties to this criteria are TK6063, HIDO and SHEMALL.

In result of study, moreover, we found that these varieties were advisable to grow in Igdir conditions.

Hallauer A.R, Carena M.J, Miranda M.J, 1987. Quantitative Genetics in Maize Breeding. Iowa State Univ. Press, Ames, Iowa. ISBN 978-1-4419-0765-3.

İptaş S, Öz A, Boz A, 2002. The Growing Possibilities of Silage Maize as First Crop in Tokat Kazova Conditions. Journal of Agricultural Sciences, 8(4):267-273

Keskin B, Akdeniz H, Y1lmaz İ.H, Turan N, 2005. Yield and Quality of Forage Corn (Zea mays L) as Influenced by Cultivar and Nitrogen Rate. Journal of Agronomy 4(2):138-141.

Kilıç A, 1986. Silo Yemi (Silo Feed) (Learning and Practice Recommendations), Bilgehan Press, Bornova Izmir, Turkey, p 327.

Kün E, 1997. Grains II (Warm Climate Cereals). Ankara University Agricultural Faculty Textbook,.Pub. No:1360, Ankara, p 141.

Sade B, 2002. Corn Agriculture. Konya Commodity Exchange Pub. No: 1. Konya.

Sağlamtimur T, Tans1 V, Baytekin H, 1998. Forage Crops Cultivation. Cukurova University Agricultural Faculty Textbook No:74. Adana.

SPSS Inc., 1991. Statistical Package For The Social Sciences (SPSS/PC+). Chicago, IL.

Temel S, Tan M, 2002. A Research on Determination of Seeding and Cutting Time in Common Vetch (Vicia sativa L.) Under Erzurum Conditions. Journal of the Faculty of Agriculture, 33(4):363-368. 